\title{
Geometric morphometric analysis of Protoconites minor from the Cambrian (Terreneuvian) Yanjiahe Formation in Three Gorges, South China
}

\author{
Junfeng Guo, Yanlong Chen, Zuchen Song, Zhifei Zhang, Yaqin Qiang, \\ Marissa J. Betts, Yajuan Zheng, and Xiaoyong Yao
}

\begin{abstract}
The Ediacaran to Cambrian transition is a critical interval of time during which major evolutionary changes occurred. Recently, abundant Protoconites minor have been recovered from the silty shales of the lower Cambrian Yanjiahe Formation (Terreneuvian, Fortunian - Stage 2) in the Three Gorges area of South China. These fossils represent an important ecological diversification of macroscopic organisms at the onset of the Cambrian. Protoconites minor is a probable cnidarian-grade organism preserved by carbon compression. Herein, geometric morphometric analyses are applied to crack out specimens of $P$. minor to reveal any cryptic morphological details that may have implications for their morphological diversity, ontogenetic processes, and taxonomic identification. These statistical analyses reveal a strong relationship between size and shape, which indicates that the overall shape of $P$. minor was mainly controlled by allometric growth. The smaller specimens are generally wider at the anterior and more commonly have straight-sides. Larger individuals tend to be narrower at the anterior, with bending more common. Our analyses demonstrate that there are transitional forms between larger, strongly bent specimens and smaller, straight specimens, suggesting that the assemblage likely consists of a single species.
\end{abstract}

Junfeng Guo. School of Earth Science and Resources, Key Laboratory of Western China's Mineral Resources and Geological Engineering, Ministry of Education, Chang'an University, Xi'an 710054, China; Early Life Institute, Shaanxi Key Laboratory of Early Life and Environments, State Key Laboratory of Continental Dynamics and Department of Geology, Northwest University, Xi'an, 710069, China; State Key Laboratory of Palaeobiology and Stratigraphy (Nanjing Institute of Geology and Palaeontology, CAS), Nanjing 210008, China. junfengg@chd.edu.cn

Yanlong Chen.Early Life Institute, Shaanxi Key Laboratory of Early Life and Environments, State Key Laboratory of Continental Dynamics and Department of Geology, Northwest University, Xi'an, 710069, China. chenyanlong4304103@hotmail.com ( ${ }^{*}$ Author for correspondence)

Zuchen Song. School of Earth Science and Resources, Key Laboratory of Western China's Mineral

Guo, Junfeng, Chen, Yanlong, Song, Zuchen, Zhang, Zhifei, Qiang, Yaqin, Betts, Marissa J., Zheng, Yajuan, and Yao, Xiaoyong. 2020. Geometric morphometric analysis of Protoconites minor from the Cambrian (Terreneuvian) Yanjiahe Formation in Three Gorges, South China. Palaeontologia Electronica, 23(3):a46. https://doi.org/10.26879/943

palaeo-electronica.org/content/2020/3183-analysis-of-protoconites-minor 
Resources and Geological Engineering, Ministry of Education, Chang'an University, Xi'an 710054, China. 757542074@qq.com

Zhifei Zhang. Early Life Institute, Shaanxi Key Laboratory of Early Life and Environments, State Key Laboratory of Continental Dynamics and Department of Geology, Northwest University, Xi'an, 710069, China. zhangelle@126.com

Yaqin Qiang. School of Earth Science and Resources, Key Laboratory of Western China's Mineral Resources and Geological Engineering, Ministry of Education, Chang'an University, Xi'an 710054, China. 2695489023@qq.com

Marissa J. Betts. Early Life Institute, Shaanxi Key Laboratory of Early Life and Environments, State Key Laboratory of Continental Dynamics and Department of Geology, Northwest University, Xi'an, 710069, China and Palaeoscience Research Centre, School of Environmental and Rural Science, University of New England, Armidale, New SouthWales 2351, Australia. marissa.betts@une.edu.au Yajuan Zheng. School of Earth Science and Resources, Key Laboratory of Western China's Mineral Resources and Geological Engineering, Ministry of Education, Chang'an University, Xi'an 710054, China. yajuanzheng@126.com

Xiaoyong Yao. School of Earth Science and Resources, Key Laboratory of Western China's Mineral Resources and Geological Engineering, Ministry of Education, Chang'an University, Xi'an 710054, China. yaoxy@chd.edu.cn

Keywords: Terreneuvian; Yanjiahe Biota; Protoconites minor; geometric morphometrics; morphospace Submission: 12 November 2018. Acceptance: 20 September 2020.

\section{INTRODUCTION}

During the late Ediacaran to middle Cambrian (635 to $505 \mathrm{Ma}$ ), fundamental biological, climatic, tectonic, and geochemical changes occurred (Zhu et al., 2003, 2007; Meert and Lieberman, 2004, 2008). The abrupt appearance of most major animal phyla in the early Cambrian is known as the Cambrian Radiation. Key early Cambrian fossils include ichnofauna, small shelly fossils (SSF), and exquisitely preserved soft-bodied fossils found in numerous, globally distributed lagerstätten, which are critical for understanding the diversity present in Cambrian ecosystems (Conway Morris et al., 1987; McCall, 2006; Li et al., 2007; Steiner et al., 2007; Shu, 2008, Shu et al., 2014; Zhang et al., 2014).

Limitations of the fossil record mean that the deep origins of animal phyla remain cryptic, primarily because early ancestors were often small and/ or soft-bodied, with reduced preservation potential. Therefore, it has been suggested that the roots of animal evolution extend back into the Precambrian (Wray et al., 1996; Bromham et al., 1998; Aris-Brosou and Yang, 2003; Peterson et al., 2004, 2008; Blair, 2009; Zhang et al., 2014; Zhu et al., 2017; Cai et al., 2019). Linking the evolutionary relationships of the fossil communities of the late Precambrian with the small shelly fossils and soft-bodied taxa of the early Cambrian is a fundamental challenge. It is rare for small shelly fossils to be pre- served in the same deposits as soft-bodied macrofossils (Guo et al., 2017). However, the early Cambrian Yanjiahe Biota bridges this gap as it includes macroscopic metazoans, macroalgae, small shelly fossils, spheroidal fossils (putative embryos), acritarchs, and cyanobacteria (Guo et al., 2008, 2009, 2010a, b, 2012, 2014, 2017, 2020a, b, c; Topper et al., 2019). Importantly, some key macrofossils exhibit characters of a transitional biota from Ediacaran to Cambrian, such as some types of macroalgae (Guo et al., 2010a) and the cnidarian-grade Protoconites (Guo et al., 2009).

Guo et al. (2009) reported Protoconites sp. from the lower Cambrian Yanjiahe Formation (Fm.) in the Three Gorges area, Hubei Province, South China. Chang et al. (2018a) redescribed similar specimens from the same interval in the Yanjiahe Fm., Shuijingtuo Fm., and Shipai Fm., and reassigned Protoconites (the Yanjiahe Fm.) to Cambrorhytium cf. major. However, Protoconites specimens lack key features such as the tentaclelike structures and the transverse annulations seen in Cambrohytium (Xiao et al., 2002), hence the specimens herein are referred to Protoconites.

Protoconites minor are smooth, expanding tubes (5-50 mm long), with a pointed apex that expands to a squared-off termination or aperture. Although $P$. minor lacks tentacle-like structures and transverse annulations as in Cambrorhytium (or Archotuba conoidalis, Hou et al., 1999) and similar 
genera such as Lantianella and Piyuania, overall size and morphological similarities may implicate a close phylogenetic relationship between these taxa (Conway Morris and Robinson, 1988; Chen et al., 1996; Chen and Zhou, 1997; Hou et al., 1999, 2004; Xiao et al., 2002; Chen, 2004; Ponomarenko, 2005; Zhang and Hua, 2005; Guo et al., 2009, 2017; Yuan et al., 2011, 2016; Wan et al., 2016).

The biological affinities of many Precambrian and Cambrian conical fossils have been extensively debated (Conway Morris and Robinson, 1988; Chen et al, 1994; Xiao et al., 2002; Ponomarenko, 2005; Guo et al., 2009, 2017; Yuan et al., 2011, 2016; Wan et al., 2016; Chang et al., 2018a). Hyoliths for example, have been traditionally grouped with molluscs, but new data regarding soft morphology has resulted in their controversial reinterpretation as lophophorates (Moysiuk et al., 2017; Sun et al., 2018). Although they are broadly morphologically similar to some hyoliths, Protoconites minor lacks a mineralized skeleton (Xiao et al., 2002). Protoconites minor are enigmatic fossils, with interpretations ranging from cnidarians to algae (Xiao et al., 2002). They have a long stratigraphic range, from the Ediacaran [upper Doushantuo Fm. black shales at Miaohe, Yichang city, Hubei Province (Chen et al., 1994; Ding et al., 1996; Chen et al., 2002; Xiao et al., 2002; Yuan et al., 2002) and at Taoying, Jiangkou county, Guizhou Province (Zhao et al., 2004; Wang et al., 2005, 2011)] to the lower Cambrian [Yanjiahe Fm., Hubei Province (Guo et al. 2008, 2009; Chang et al., 2018a)].

Xiao et al. (2002) suggested that Protoconites minor could be a juvenile form of Baculiphyca taeniata (clavate forms with rhizoidal holdfasts from the Ediacaran Miaohe Biota). This seems unlikely, however, as $P$. minor exhibits a larger divergent angle and lacks a rhizoidal holdfast. P. minor also bears close similarities to the Cambrian Cambrorhytium in size, shape, and style of preservation (Conway Morris and Robinson, 1988; Chen et al., 1996; Chen and Zhou, 1997), but lacks faint tentacle-like structures and transverse annulations. Cambrorhytium major has been interpreted as a possible scyphozoan cnidarian (Conway Morris and Robison, 1988), comparable to the sheaths that enclose budding polyps in coronate scyphozoans such as modern Stephanoscyphus (Werner, 1966).

As Protoconites minor fossils exhibit high morphological diversity, total species presence remains uncertain. In general, smaller specimens are generally wider at the anterior part, with straight sides, and larger specimens are relatively narrower at the anterior, and often exhibit some degree of lateral bending. Specimens with the wide apertures were interpreted as a different species to those with narrow apertures, such as Cambrorhytium (C. major, C. cf. C. major, C. fragilis, C. minor and C. gracilis) (Conway Morris and Robison, 1988; Ponomarenko, 2005; Zhang and Hua, 2005; Chang et al., 2018a) and Sphenothallus (S. taijiangensis, S. songlinensis, and S. kozaki) (Zhu et al., 2000; Peng et al., 2005; Chang et al., 2018a). Alternatively, these morphological differences may be due to intraspecific variation.

Abundant Protoconites minor from the lower Cambrian Yanjiahe $\mathrm{Fm}$. provide an excellent opportunity to test this using geometric morphometrics. The development of geometric morphometrics in the last two and a half decades was a "quantification revolution" for the analysis of shape (Adams et al., 2004; Chen et al., 2016). The method has been demonstrated as a very powerful tool for the study of diversity and evolution of life (e.g., Cooney et al., 2017). Sliding semilandmarksbased geometric morphometrics have a similar function to elliptical Fourier analyses when analyzing the shapes of outlines. However, the sliding semilandmark approach is more effective in circumstances where emphasis must be placed on particular segments, which can be easily achieved by using more points. Herein, we apply a combination of landmark and semilandmark-based geometric morphometric analyses to $P$. minor in order to explore their morphological space, and reveal any taxonomical information associated with morphology, and to determine whether overall shape change is associated with changes in size.

\section{LOCALITY AND STRATIGRAPHY}

All Protoconites minor utilized in this study were collected from four measured stratigraphic sections (the Dingjiaping, Gunziao, Yangjiachong, and Muyang sections) through the Yanjiahe Fm. in the Three Gorges area, South China (Figure 1.14). The Yanjiahe Fm. crops out mainly around the southern and western flanks of the Huangling Anticline, as well as the core of the Changyang Anticline, (Figure 1.1-2). The succession is particularly well-developed and well-exposed around the Yanjiahe Village (Sandouping Town) and the Dingjiaping Village (Changyang County) in the Yichang area (Figure 1.3-4).

The Yanjiahe Fm. rests unconformably on the underlying dolomitic Baimatuo Member of the 


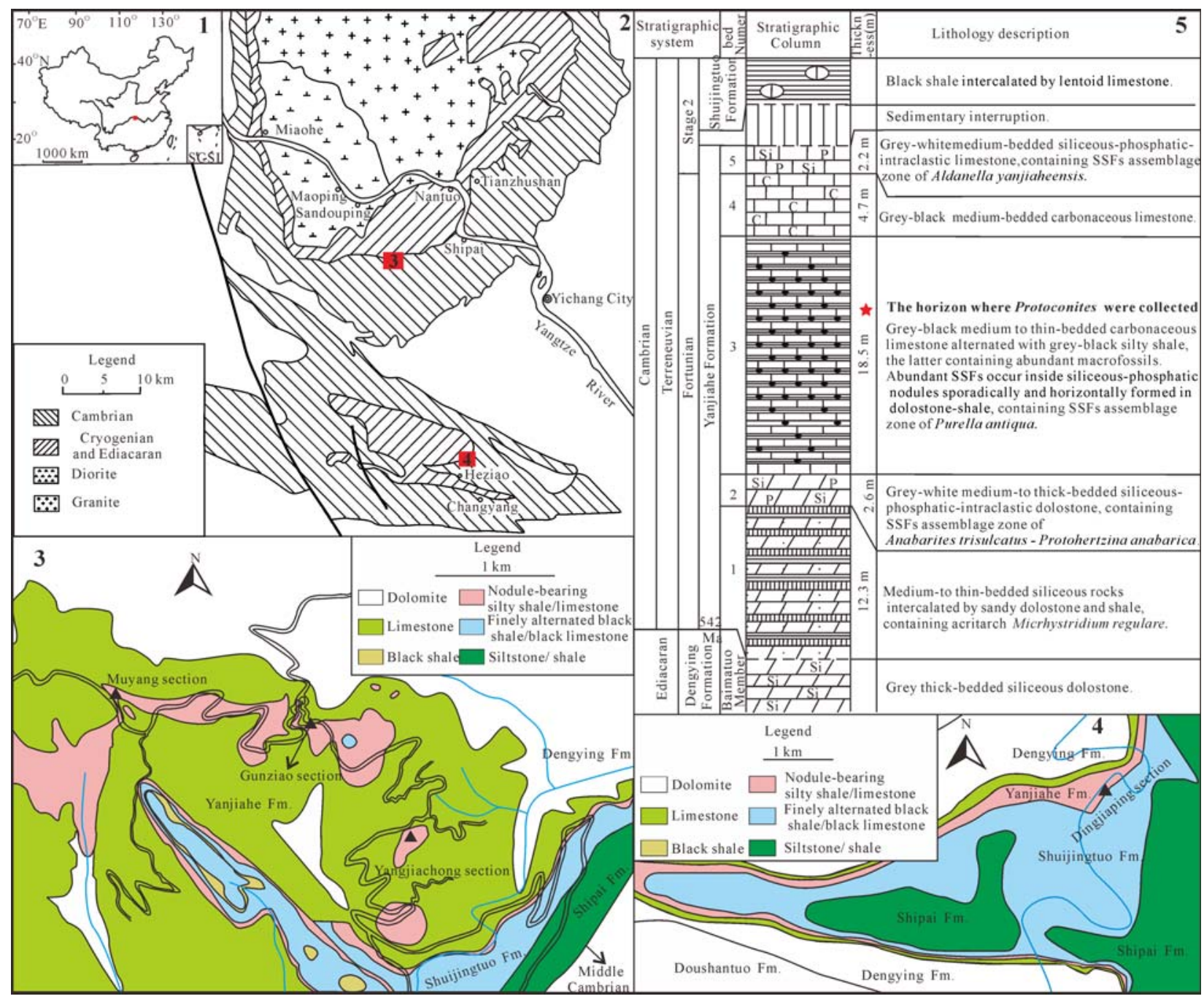

FIGURE 1. Locality and stratigraphy of the Cambrian (Terreneuvian) Yanjiahe Formation in Yichang, Hubei Province, China. 1. Sketch map of the People's Republic of China, showing the position of the collecting locality in Hubei Province; 2. Simplified geological sketch map of the Three Gorges area, Hubei Province, South China, showing the outcrops of Cambrian strata. Red boxes around $\mathbf{3}$ (Yanjiahe area) and $\mathbf{4}$ (Dingjiaping area) denote areas that are enlarged for additional detail; 3. Detailed geological sketch map of the Yanjiahe area, showing the outcrops of the Yanjiahe Formation; 4. Detailed geological sketch map of the Dingjiaping area, showing the outcrops of the Yanjiahe Formation. (In 3 and 4 map: White = Ediacaran Dengying Formation; Pink and light green = Cambrian Yanjiahe Formation; Yellow and light blue $=$ the Cambrian Shuijingtuo Formation; Green = Cambrian Shipai Formation; Black triangles indicate locations of measured stratigraphic sections) 5. Stratigraphic sequence of Lower Cambrian strata in the Gunziao section, Three Gorge area, indicating the horizons where fossils were collected.

Dengying Fm. (Ediacaran). The Yanjiahe Fm. is subdivided on the basis of lithology into five beds (Figure 1.5). In the Gunziao section, Bed 1 is about $12.3 \mathrm{~m}$ thick and consists of siliciclastics intercalated with sandy dolostone and shale. Bed 1 contains the Asteridium-HeliosphaeridiumComasphaeridium acritarch assemblage zone (Yao et al., 2005; Dong et al., 2009; Ahn and Zhu, 2017) and probable sponge spicules (Chang et al., 2017). Bed 2 is $2.6 \mathrm{~m}$ thick and consists of sili- ceous-phosphatic intraclastic dolostones bearing shelly fossils from the Anabarites trisulcatus-Protohertzina anabarica Assemblage Zone (Guo et al., 2014), in addition to the tubular taxon Megathrix longus (Shang et al., 2016). Bed 3 is about $18.5 \mathrm{~m}$ thick and consists of grey-black limestone interbedded with silty shale. The silty shale contains macrofossils such as algae and enigmatic metazoans (Yanjiahella and Protoconites minor studied herein) (Guo et al., 2008, 2009, 2010a, 2012; Topper et al., 
2019). Abundant shelly fossils (Purella antiqua Zone) (Guo et al., 2014) and the possible earliest radiolarian (Chang et al., 2018b) occur in siliceousphosphatic nodules in Bed 3. Bed 4 is $4.7 \mathrm{~m}$ thick and consists of non-fossiliferous carbonaceous limestone. Bed 5 is about $2.2 \mathrm{~m}$ thick and consists of siliceous-phosphatic, intraclastic limestone containing fossils assigned to the Aldanella yanjiaheensis Assemblage Zone $(=A$. attleborensis Assemblage Zone, corresponding to the Watsonella crosbyi assemblage (Terreneuvian, Stage 2), Guo et al., 2014, 2020c).

Ahn and Zhu (2017) suggest that the Yanjiahe Fm. records the biogeochemical history of the South China platform throughout approximately the first $15 \mathrm{Ma}$ of the Cambrian Period. There is a disconformity between the Yanjiahe Fm. and the overlying Shuijingtuo Fm., representing a relatively minor time-gap (Chen, 1984; Ding et al., 1992; Guo et al., 2008, 2009). The U-Pb age from zircons at the base of the Shuijingtuo Fm. in the Three Gorges area give an age of 526.4 $\pm 5.4 \mathrm{Ma}$ (Okada et al., 2014).

\section{MATERIAL AND METHODS}

All 1048 specimens (see Appendix, supplementary Table S1) of Protoconites minor utilised for this study occur as carbonised films preserved on bedding surfaces (Figure 2). Obviously broken or extensively damaged specimens have been excluded from the analysis. Collection number " $\mathrm{CH}$ " indicates fossils from the Dingjiaping section. " $Y$ " indicates fossils from the Yangjiachong section. Digital images were taken with a light camera (Canon EOS70D) under both natural light and with an external light source in Chang'an University, Xi'an, China. Specimens are housed in the collections at the School of Earth Science and Resources, Chang'an University.

Geometric morphometric analyses required application of a combination of landmarks and sliding semilandmarks. Landmarks were used to cover static homologous anatomical loci that can be found unambiguously on every specimen (Zelditch et al., 2004), while sliding semilandmarks were used to cover curves where no homologous point can be precisely defined (Bookstein, 1997a, b; Gunz et al., 2005; Mitteroecker and Gunz, 2009; Gunz and Mitteroecker, 2013). In total, three Type II landmarks (Zelditch et al., 2004) and 34 sliding semilandmarks, were applied to each specimen using the software TpsDig2 v. 2.26 (Rohlf, 2010a; Figure 3.1-2). A sliders file was generated using the software TpsUtil v. 1.74 (Rohlf, 2011a).
Relative Warp (RW) analyses were carried out using the software TpsRelw $v 1.74$ (Rohlf, 2010b) using the Generalized Procrustes Analysis superimposition method (Figure 3.3; Zelditch et al., 2004; Gunz and Mitteroecker, 2013; Chen et al., 2016). The centroid is a measure of size that is mathematically independent of shape (Zelditch et al., 2004), and was calculated using the mean of all the landmarks' coordinates automatically using TpsRelw v 1.74. Multivariable linear regression analyses were conducted using TpsRegr v 1.45 (Rohlf, 2011b). Data was also transferred to the Palaeontological Statistics Program (PAST) (Hammer et al., 2001) for simple linear regression.

Some specimens exhibit left or right curvature. As Protoconites minor was not mineralized, it is possible that extent of curvature is a taphonomic artefact. To control for bias associated with direction of curvature, we have reflected some of the images so all specimens curve in the same direction.

\section{RESULTS}

\section{Size Spectra of Protoconites minor in the Yanjiahe Formation}

The centroid size distribution for all specimens $(\mathrm{n}=1048)$ ranged from $5.24 \mathrm{~mm}$ to $50.8 \mathrm{~mm}$. A Shapiro-Wilks test indicated a right-tailed, non-normal distribution (Figure 4.1; $W=0.9885, p<0.001$; Skewness $=0.2683$; see supplementary Table S1). Specimens were then divided into those with obvious curvature and those without, and each group was analysed separately. The total distribution of the centroid size of "straight"-sided specimens ( $\mathrm{n}=$ 722) ranges from $5.1 \mathrm{~mm}$ to $49.4 \mathrm{~mm}$, and also shows a right-tailed non-normal distribution (Figure 4.2; Shapiro-Wilks test $W=0.9905, p<0.001$; Skewness $=0.2526$; see supplementary Table S2).

\section{Geometric Morphometric Analysis of Original Shape}

To explore morphospace of Protoconites minor, we carried out Relative Warp (RW) analysis (Zelditch et al., 2004). In total, 1048 specimens were included in this analysis. Seventy relative warp (RW) scores were given by the analysis (see supplementary Table S1). RW 1 explains $38.79 \%$, RW 2 explains $34.74 \%$, and RW 3 explains $8.97 \%$ of the total variation. As shown in Figure 5.1, the average shape is straight-sided and triangular, located at the plot's origin, and RW 1 mainly explains the direction of bending. Positive and negative RW 1 scores explain different directions and 


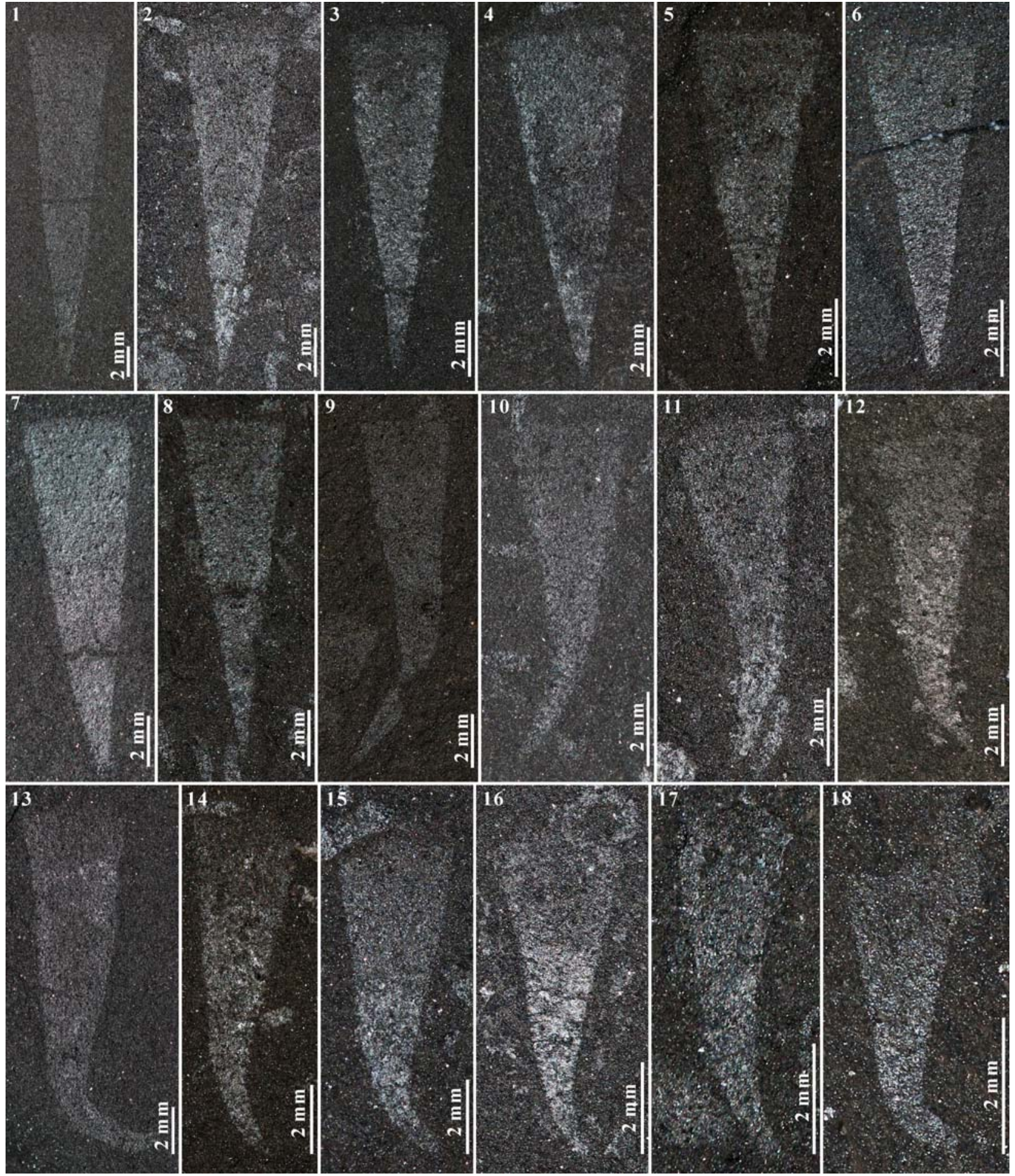

FIGURE 2. Protoconites minor from the Cambrian (Terreneuvian) Yanjiahe Formation in Yichang, Hubei, China. 1. No. Y-24B (2); 2. No. Y-41A (5)-1; 3. No. Y-765A (3); 4. No. Y-127B (1); 5. No. Y-28 (2); 6. No. CH-179A (3); 7. No. Y-273A (1); 8. No. Y-41A (14); 9. No. Y-445 (2); 10. No. Y-494 (2)-2; 11. No. Y-40A (11); 12. No. Y-1234 (3); 13. No. Y-844A (2); 14. No. Y-785 (2); 15. No. Y-40B (9)-1; 16. No. Y-880 (6); 17. No. Y-596 (2)-1; 18. No. Y-531 (3)-2. "CH" means the locality of the fossils from Dingjiaping section, " $Y$ " means the locality of the fossils from Yangjiachong section. 


\section{Aperture}
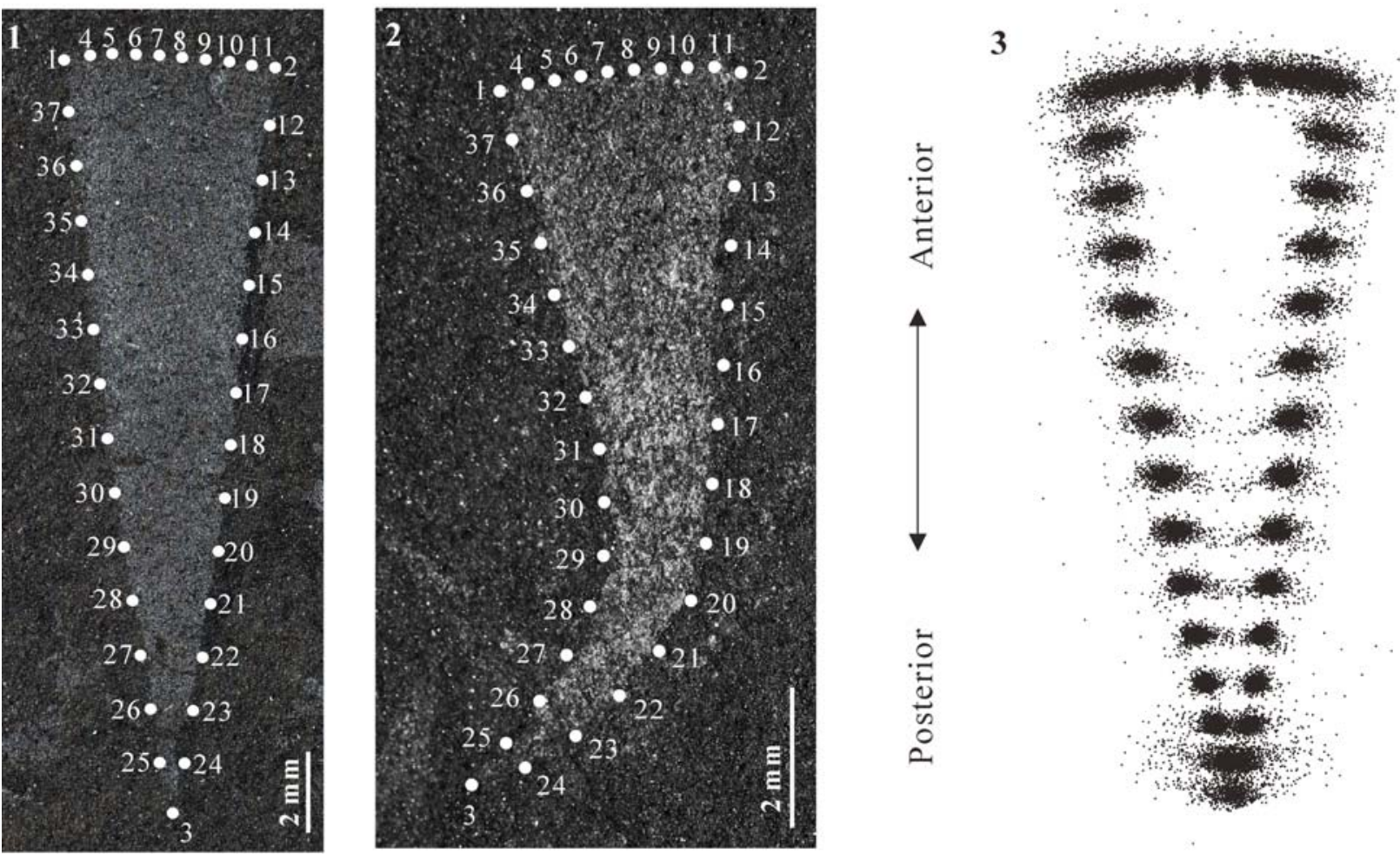

Apex

FIGURE 3. Definition of landmarks and semi-landmarks and the result of superimposition. 1. and 2. landmarks and semi-landmarks set on both straight and laterally bent specimens. Type II landmarks are 1, 2, and 3, and sliding semilandmarks are 4-34 in 1. and 2.; 3. consensus configuration after superimposition using Generalized Procrustes Analysis.

degree of bending (Figure 5.1). RW 2 mainly explains the relative width of the specimen. Specimens with a relatively wider anterior have positive RW 1 scores, while specimens which have an elongated slender shape, have negative RW 1 scores. RW 3 scores indicate variable twisting through the length of the specimens (Figure 5.2).
Specimens mainly cluster around the origin where the mean shape is straight.

\section{Geometric Morphometric Analyses of Revised Data}

Morphospace of overall specimens $(n=1048)$. Because Protoconites minor is not mineralized, bending observed in many individuals is likely to be

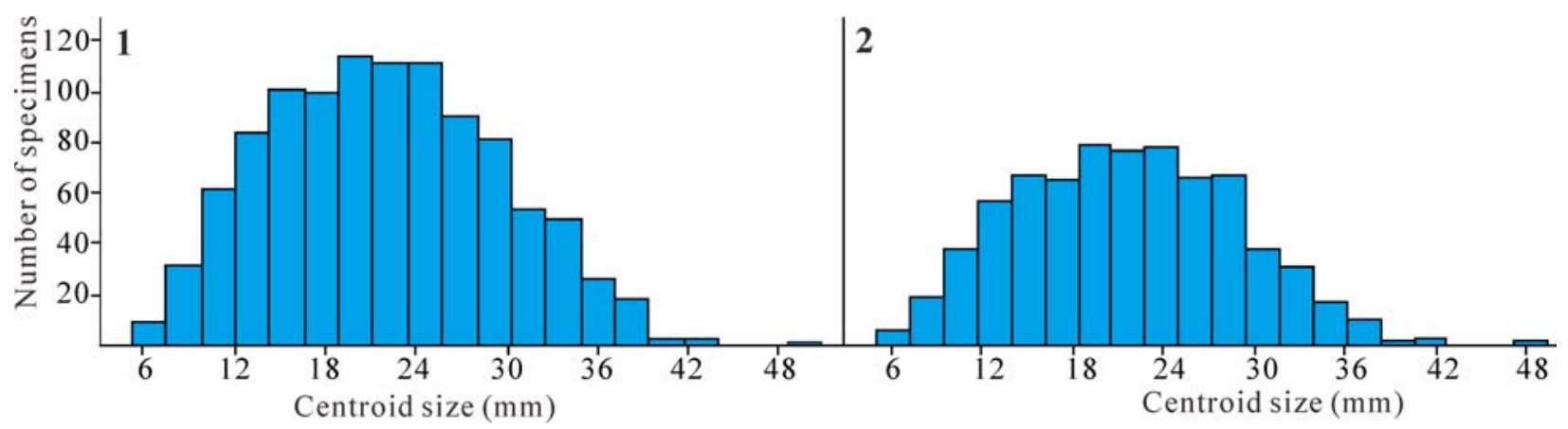

FIGURE 4. Histogram showing the size spectra of Protoconites minor. 1. size distribution of all specimens analyzed in this study; 2. size distribution without laterally bended specimens. 


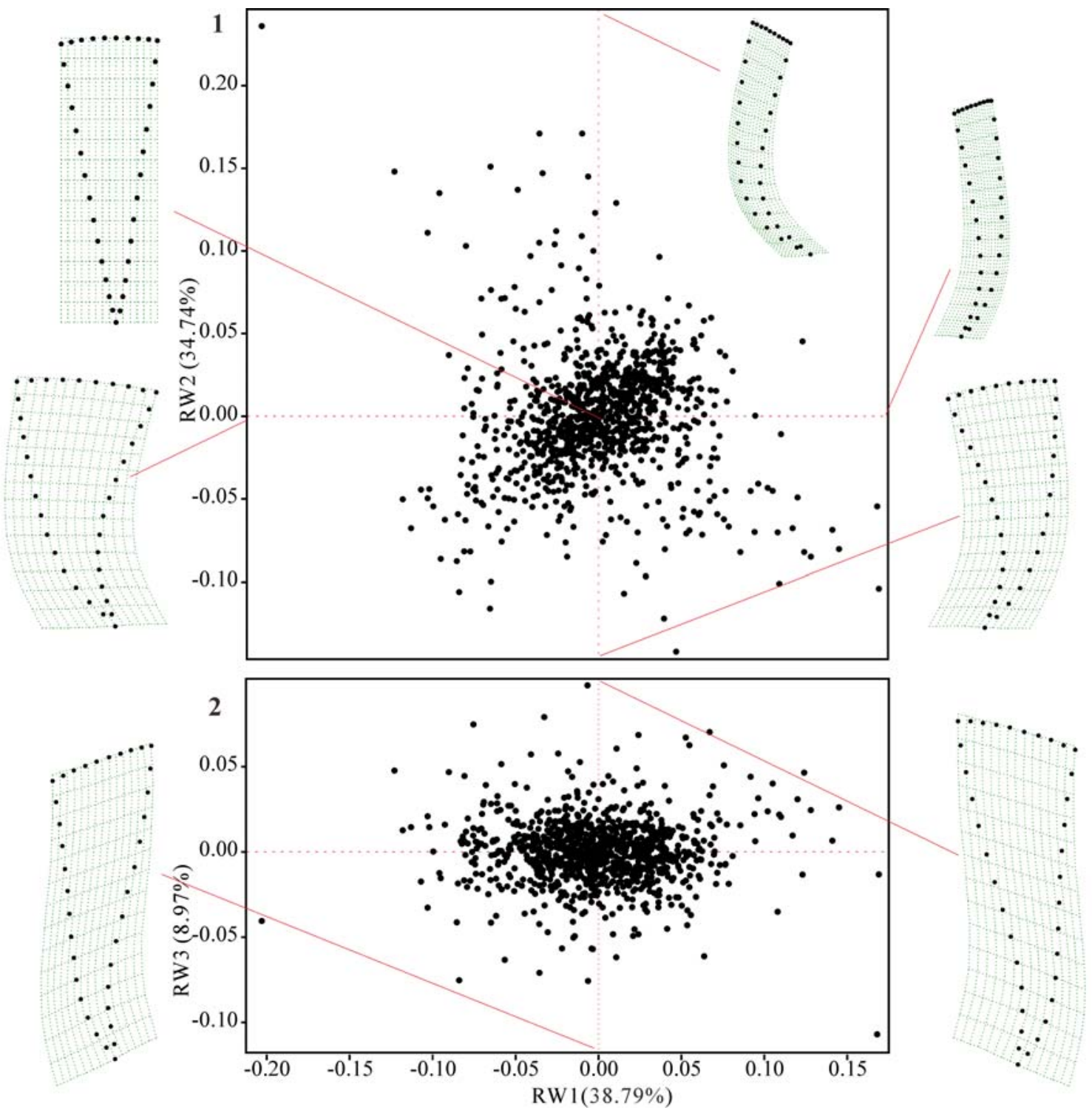

FIGURE 5. Protoconites minor morphospace generated by the Relative Warp (RW) analysis using un-mirrored specimens with indication of characteristic thin-plate splines. 1. plot for RW 1-2; 2. plot for RW 1-3. Thin-plate splines show the shapes of specimens in RW 1-2 and RW 1-3 planes, respectively.

taphonomic. To mitigate taphonomic bias, images of the bent specimens were mirrored so all that exhibited curvature did so in the same direction. In total 1048 specimens were included in this analysis and 70 relative scores are reported (see supplementary Table S3). The RW 1 explains $41.41 \%$ of the total shape variance (Figure 6.1), which mainly reflects the width of the aperture. RW 2 explains $31.82 \%$ of the total shape variance, reflecting both the width of aperture and the extent of lateral bending. Positive values of RW 2 indicates relatively narrow specimens and a slightly left side concave, while negative values of RW 2 suggests the specimen was wide and right side concave (Figure 6.1).
Herein the RW 3 explains $11.35 \%$ of the total shape variance, and indicates degree of tortuosity (Figure 6.2).

Morphospace of "straight"-sided specimens

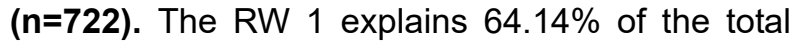
shape variance (Figure 7.1), followed by $13.11 \%$ of RW 2, 8.74\% of RW 3, and $5.46 \%$ of RW 4 . RW 1 explains mainly the relative width of the aperture of these specimens (see supplementary Table S2). RW 2 mainly shows the difference of tortuosity, with the positive and negative values indicating different directions of torsion. RW 3 mainly indicates the difference of the width of the central part of the specimens. Specimens with negative values have 


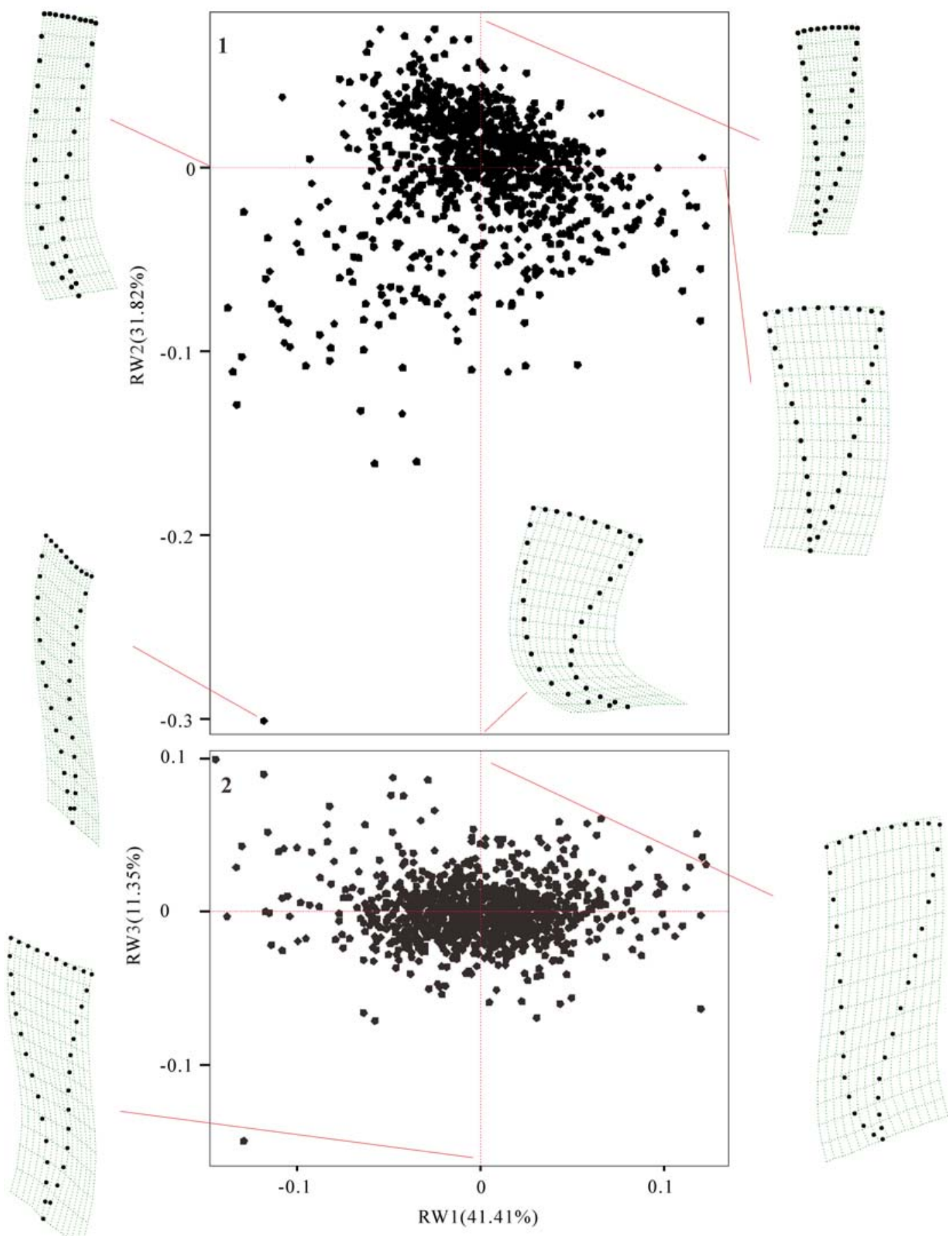

FIGURE 6. Protoconites minor morphospace generated by the Relative Warp (RW) analysis using mirrored specimens. 1. plot for RW 1-2; 2. plot for RW 1-3. All thin-plate splines correspond to points (indicated as a line) within the morphospace in RW 1-2 and RW 1-3 planes, respectively.

a narrow central part, while specimens with positive RW 3 values are expanded through the centre (Figure 7.2).

Morphospace of bent specimens $(n=326)$. The RW 1 explains $42.06 \%$ of the total shape variance, followed by $27.18 \%$ of RW $2,13.80 \%$ of RW 3 , and $6.24 \%$ of RW 4 (see supplementary Table S4). RW 1 reflects both the extent of lateral bending and tortuosity. RW 2 mainly shows the difference of the relative width of the aperture. 


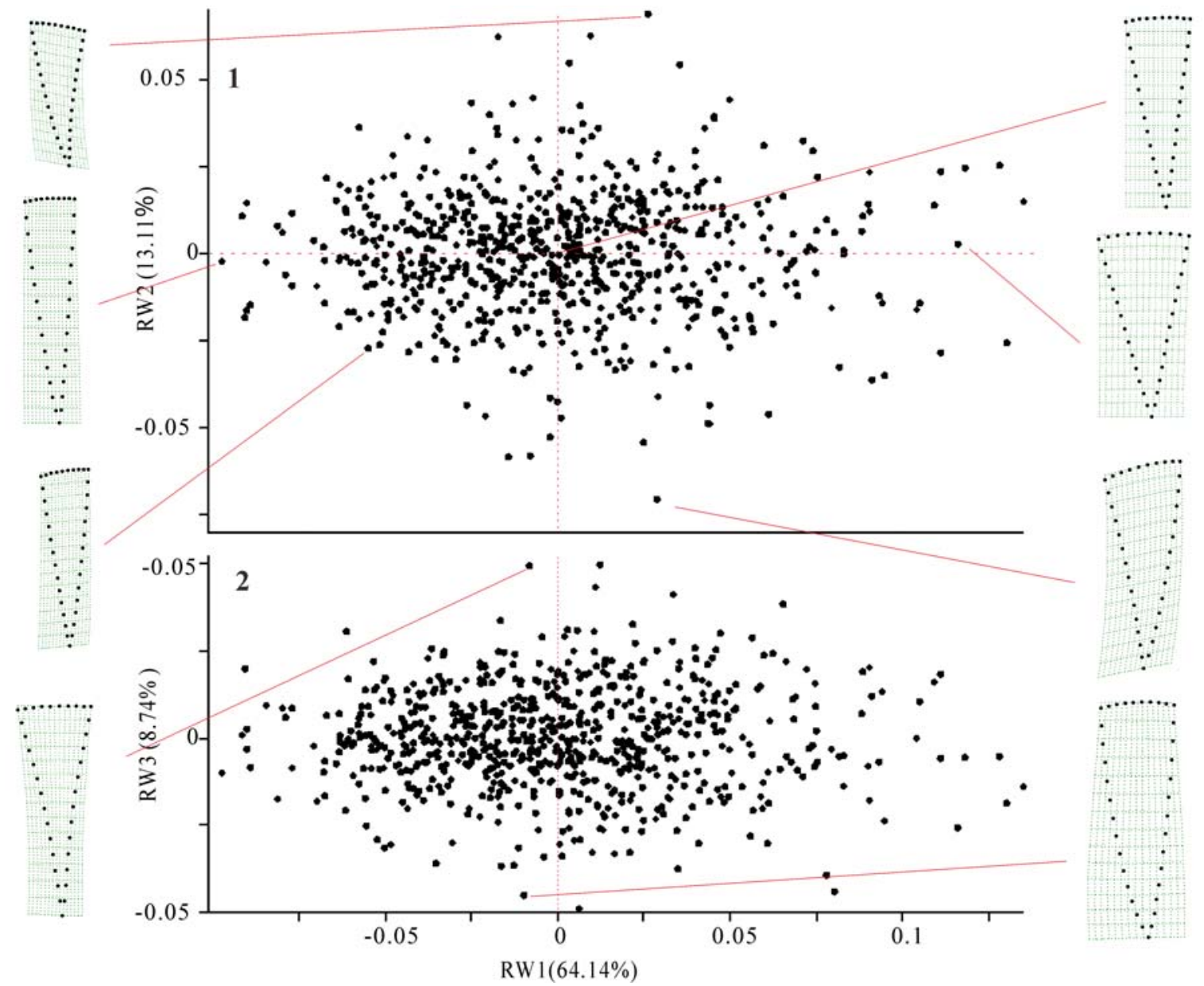

FIGURE 7. Morphospace of straight shell Protoconites minor generated by the Relative Warp (RW) analysis. 1. plot for RW 1-2; 2. plot for RW 1-3. All thin-plate splines correspond to the shapes of specimens in RW 1-2 and RW 1-3 planes, respectively.

\section{Linear Regression Analyses}

Linear regression of overall specimens $(n=1048)$. To reveal if shape is related to ontogenetic allometry, we conducted multivariable linear regression analysis between the overall shape variance (generalized least squares aligned by tpsRelw v. 1.65) and the log10-transformed centroid size of 1048 specimens using the software TpsRegr $v$ 1.45. This indicates a strong relationship between size and shape (Generalized Goodall Ftest: $F=235.856, p<0.001$; Wilks' Lambda test: $\lambda$ $=0.437, p<0.001$; see supplementary Table S3 for 1000 permutation test). A linear regression analysis using the method of ordinary least-squares was also carried out between RW 1 and centroid size with the software PAST (Hammer et al., 2001) to visualize the relationship between shape and size (Figure 8). This indicates a significant relationship between shape and RW 1 (mainly specimen width) $\left(r^{2}=0.340 ; p<0.001\right.$; see supplementary Table S3). Small, specimens are generally wider at the anterior part, and commonly have straight sides. Larger specimens are relatively narrower at the anterior. In addition, more of the larger specimens exhibit lateral bending.

Linear regression of "straight"-sided specimens $(n=722)$. Multivariable linear regression analysis between the overall shape (Generalized least squares aligned by TpsRelw v. 1.65) variance and the log10-transformed centroid size of these 722 specimens was conducted by the software TpsRegr $v$ 1.45. The analysis suggests an even stronger relationship between shape and size than the analysis including bent specimens (Generalized Goodall F-test: $F=333.808, p<0.001$; Wilks' Lambda test: $\lambda=0.391, p<0.001$; see supplementary Table S2 for 1000 permutation test). We also conducted a simple linear regression analysis between RW 1 and centroid size by the software 


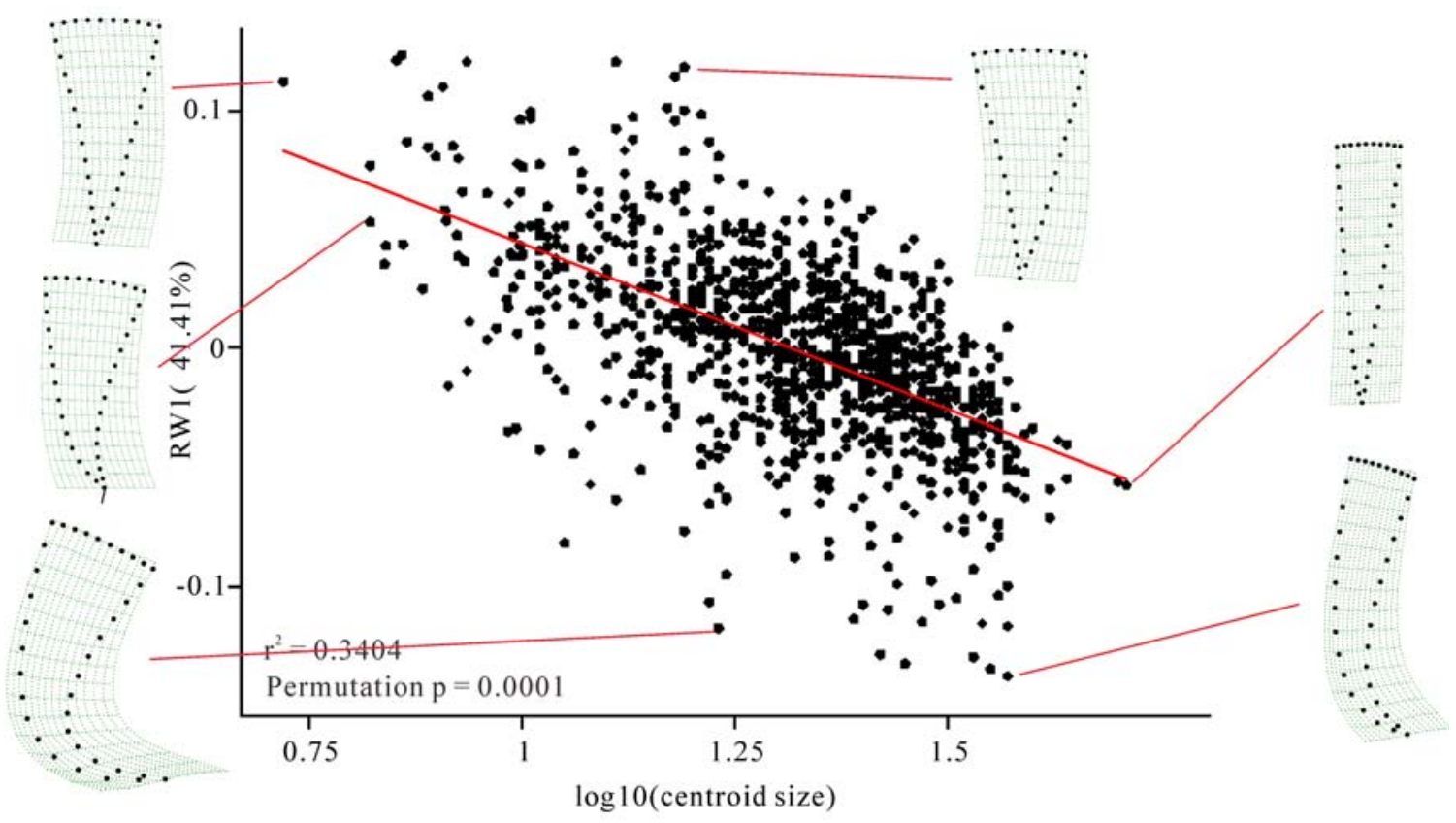

FIGURE 8. The ordinary least-squares linear regression of the shape of mirrored Protoconites minor with $\log _{10-}$ transformed centroid size. Characteristic specimens are shown in thin-plate splines corresponding to the shapes of specimens in RW 1-2 plane.

PAST (Hammer et al., 2001). The analysis indicates a significant relationship between centroid size and RW $1\left(r^{2}=0.486 ; p<0.001\right.$; see supplementary Table S2; Figure 9). Small specimens have positive RW 1 scores, which normally indicate a wider aperture. While large shells have negative RW 1 scores, indicating a relatively narrow anterior.

Linear regression of bent specimens $(n=326)$. Multivariable linear regression analysis between the overall shape variance and the log10-transformed centroid size of these 326 specimens was conducted using the software TpsRegr v1.45. The analysis suggests a poor relationship between shape and size (Generalized Goodall F-test: $F=$ 44.823, $p<0.001$; see supplementary Table S4 for 1000 permutation test). A simple linear regression analysis between RW 1 and centroid size by the software PAST (Hammer et al., 2001). The analysis indicates no obvious relationship between centroid size and RW $1\left(r^{2}=0.0071 ; p<0.13\right.$; see supplementary Table S4).

\section{DISCUSSION}

\section{Size Spectra}

The body size of an animal is a key trait impacting prey capturing, longevity, reproductive success, food acquisition, and consumption (Hone and Benton, 2005; Bell, 2014), as well as metabolic rate (Gillooly et al., 2001). Centroid size is mathematically independent of shape and thus can be used as a proxy for true size. Numerous studies have reported positively-skewed distributions, which suggest that size spectra are a result of hydrodynamic transportation or sorting (Knouft and Page, 2003; Clauset and Erwin, 2008; O'Gorman and Hone, 2012; Chen et al., 2016). The specimens analyzed here have a wide centroid size distribution, ranging from $5.24 \mathrm{~mm}$ to $50.8 \mathrm{~mm}$ and have a right-tailed non-normal distribution. This indicates that the size distribution of Protoconites minor in the Yanjiahe Fm. is not due to transportation or sorting.

\section{Morphospace of Overall Specimens and Implications for Taxonomy}

Different species often cluster in separate regions in morphological space (e.g., Matthews and Stynder, 2011; Cruz et al., 2012). Similarly, the results of relative warp analyses can also be applied to discriminate different species, (e.g., Cruz et al., 2012; Karahan et al., 2014). RW1 of the original data (unmirrored images) with 1048 specimens (Figure 5) is related to the width of the specimen and the direction of bending, suggesting that the main shape variation of Protoconites minor is the relative width of the anterior aperture and the 


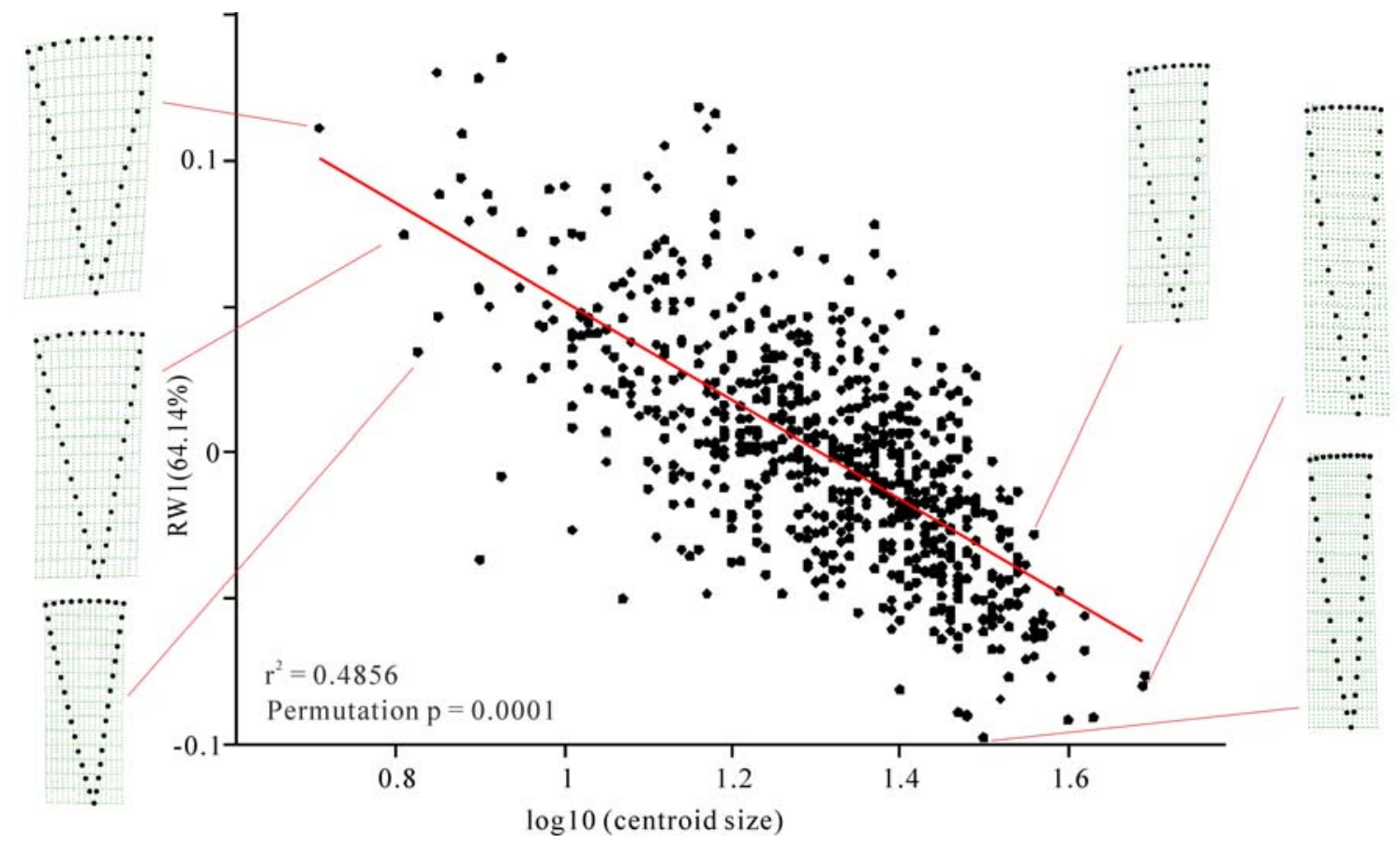

FIGURE 9. The ordinary least-squares linear regression of the shape of straight-shelled Protoconites minor with $\log _{10^{-}}$ transformed centroid size. Characteristic specimens are shown in thin-plate splines corresponding to the shapes of specimens in RW 1-2 plane.

whether they bend to the left or right. Specimens are distributed in the RW1-RW2 morphospace with the highest density around the plot's origin, indicating that most specimens are straight-sided (Figure 5). There are transitional forms between straightsided and laterally bent specimens, with no obvious clustering observed in morphospace indicating that both straight and laterally bent specimens are probably the same species.

Relative warp analysis using mirrored images (1048 specimens), in which all fossils curve to the same side, also has the highest density around the plot's origin within the RW1-RW2 of the morphospace. There are transitional forms between strongly bent specimens and straight specimens, and no obvious clustering in morphospace. Very strongly bent specimens are rare. This indicates that most specimens are more or less straight sided, and our analyses demonstrate that both straight-sided and laterally bent specimens are the same morphospecies.

\section{Morphospace of Straight-sided Specimens}

The analysis of only straight-sided specimens gives RW1 (64.14\%) scores that are strongly related to the width of the upper part of the shell (Figure 7), indicating that the morphological variation of specimen is mostly controlled by the relative width of the anterior. Within morphological space, most specimens are clustered around the plots' origin, with decreasing density away from the origin. As discussed above, the distribution of straightsided specimens within morphospace does not support the suggestion that there are multiple species within the assemblage.

\section{Allometry and Its Implications for Taxonomy}

Allometry is the study of the statistical links between shape and overall size of organisms (Mosimann, 1970; Klingenberg, 1998), and ontogenetic allometry examines the relationship between size and shape during the growth of an organism (e.g., Adams et al., 2013; Shi and MacLeod, 2016; Chen et al., 2016).

This is the first study to statistically explore allometry in the Cambrian Protoconites minor. The linear regressions indicate a strong relationship between size and shape for the total assemblage. Shape is strongly controlled by size, with small specimens having a relatively wide aperture, while large specimens have a relatively narrow aperture. Meanwhile, most strongly bent specimens are large, and almost no smaller specimens showed strong lateral bending. However, multivariable linear regression analysis between the overall shape of the 326 laterally bent specimens and the log10- 
transformed centroid size suggests a poor relationship between shape and size (see supplementary Table S4). This suggests that the bending was not developed during their ontogenetic development, and that larger individuals are more prone to bending during either pre- or postmortem taphonomic phases (Figure 8). In the "straight"-sided specimens, the linear regression indicates a very strong relationship between shape and size (Figure 9). In these specimens the relative anterior width became narrower throughout ontogeny (Figure 10 ), indicating that the main way for these organisms to increase their size is aggradation on the margin of anterior aperture, as there is no aggradation or growth on other areas.

Our analyses indicate that the morphology of Protoconites minor was mainly controlled by ontogenetic allometry. It was believed that wide anterior and narrow anterior shelled fossils may represent different species, such as Cambrorhytium (C. major, C. cf. C. major, C. fragilis, C. minor, and C. gracilis; Conway Morris and Robison, 1988; Ponomarenko, 2005; Zhang and Hua, 2005; Chang et al., 2018a) and Sphenothallus (S. taijiangensis, S. songlinensis, and S. kozaki; Zhu et al., 2000; Peng et al., 2005; Chang et al., 2018a). However, both the relative warp analysis and the linear regression analysis suggest that shape variation on Protoconites specimens belong to the same species, and different relative widths at the aperture represent different ontogenetic stages.

\section{CONCLUSIONS}

This study demonstrates the power of geometric morphometric techniques for teasing out cryptic morphological aspects of problematic organisms. These studies can clarify aspects of growth, development and taxonomy not readily ascertained by traditional methods. This is the first geometric morphometric study of the early Cambrian taxon Protoconites minor from South China. $P$. minor from the Yanjiahe $\mathrm{Fm}$. in the Three Gorges area are abundant, allowing for robust analyses of their overall shape. Morphometric analyses show that these specimens have undergone minimal transportation, mitigating any sorting or sampling bias. As $P$. minor were unmineralised, probably conical organisms, the direction and degree of bending seen in these fossils is likely to have been influenced by taphonomic factors. Relative Warp (RW) analyses indicate that the primary influence in shape variation is the relative width of the anterior aperture.
Our analyses show that the variation in the morphology of Protoconites minor is mainly controlled by ontogenetic allometry. Both the relative warp analyses and the linear regression analyses indicate that these specimens all belong to the same species: $P$. minor, and that different apertural widths represent different growth stages. The smaller specimens tend to have wider apertures relative to their length, while the larger specimens have narrow apertures relative to their length. Consequently, the variation on shape is not considered here to be a useful diagnostic character at either the generic or the specific rank.

\section{SYSTEMATIC PALAEONTOLOGY}

?Phylum Cnidaria Verrill, 1865

Class, Order and Family uncertain

Genus Protoconites Chen, Xiao, and Yuan, 1994

Type species. Protoconites minor Chen, Xiao, and Yuan, 1994; from Miaohe Biota, Three Gorges area, South China.

Protoconites minor Chen, Xiao, and Yuan, 1994

Figure 2.1-18; Figure 10.1-27

1994 Protoconites minor Chen, Xiao, and Yuan, $p$. 397, pl. IV, figures 10-11

1996 Protoconites minor; Ding et al., pl. 33, figure 9

2002 Protoconites minor; Chen et al., pl. 4, figure 6

2002 Protoconites minor; Xiao et al., p.368, figures 7.9-7.11, 7.14-7.15

2002 Protoconites minor; Yuan et al., p.65, figure 77

2004 Protoconites cf. minor; Zhao et al., figure 2(e)

2005 Protoconites; Wang et al., figure 4.2

2008 Protoconites minor; Guo et al., figure 5.(a)-(c)

2009 Protoconites sp.; Guo et al., figure 3.(a)-(e)

2011 Protoconites minor; Wang et al., figure 4.J-K

2017 Protoconites sp.; Guo et al., figures 1.1-1.2, 3.2

2018a Cambrorhytium cf. C. major; Chang et al.,figure 3.M

Types. Holotype (HBM-496) and paratype (HBM506) were designated by Chen et al. (1994) and reposited in the Nanjing Institute of Geology and Palaeontology, Academia Sinica.

Material. More than 1048 specimens from the Terreneuvian Yanjiahe Fm., in Three Gorges (mainly derived from the Dingjiaping, Gunziao, Yangjiachong, and Muyang sections). All specimens are reposited in Chang'an University.

Description. Smooth conical compressions about 5-50 mm long, with a pointed apex that expands to a squared-off termination (with the aperture). Tubes $0.2-0.4 \mathrm{~mm}$ in diameter at apex and up to 1-7 mm at aperture. Angle of divergence 13-25 

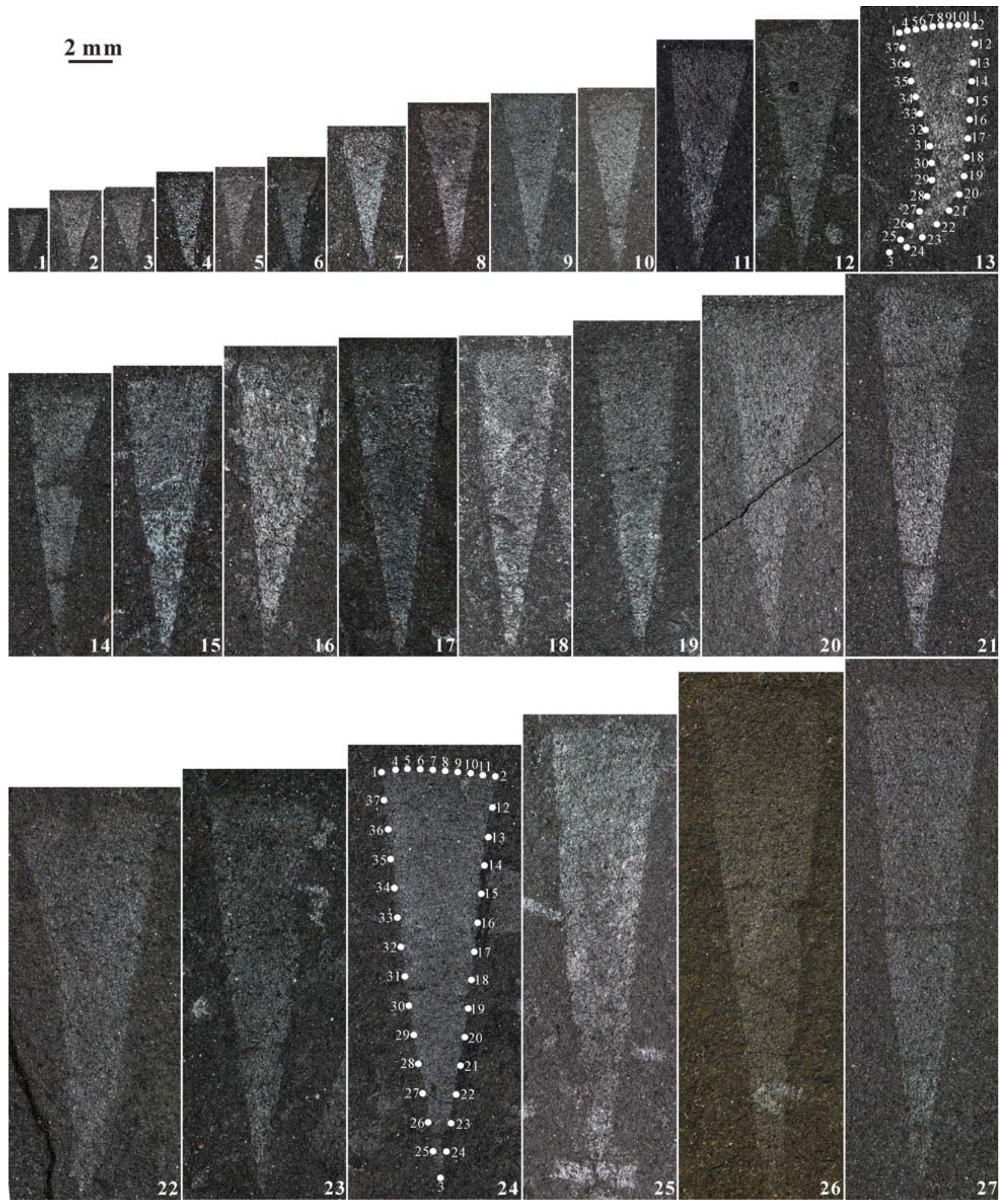

FIGURE 10. Protoconites minor from the Cambrian (Terreneuvian) Yanjiahe Formation showing morphological variance during the ontogeny. Size of these specimens increases from right to left and from top to bottom. 1. No. Y-596 (2)2; 2. No. Y-735A (20)-2; 3. No. Y-800A (19)-2; 4. No. Y-469B (5); 5. No. Y-581 (2); 6. No. Y-134 (10); 7. No. Y-523; 8. No. Y-1236 (2); 9. No. Y-29; 10. No. Y-617A (4)-3; 11. No. Y-558A (17); 12. No. Y-141A (19)-1; 13. No. Y-558A (33); 14. No. Y-617A (2); 15. No. Y-546A (2); 16. No. Y-732A (20); 17. No. Y-142A (8)-1; 18. No. Y-816A (4); 19. No. Y-1230A (45); 20. No. Y-425A (2); 21. No. Y-561A (5); 22. No. Y-567 (2); 23. No. Y-732A (32)-1; 24. No. Y-173A (4); 25. No. Y1227A (10); 26. No. Y-51A (2); 27. No. Y-24B (2). "Y" means the locality of the fossils from Yangjiachong section. 
degrees. Straight or bent at the posterior part. No preserved holdfast or tentacle-like structures; no annulations or transverse markings. During the early ontogenetic stage, they are relatively wide at the aperture. Growth is primarily by aggradation on the margin of anterior aperture. Smallest specimens show no lateral bending, however, with the increasing of size, specimens are often preserved with lateral bending.

Discussion. Protoconites bears some similarities with Cambrorhytium, a tubular form that is found in Stages 3-Wuliuan in Canada (Stephen Fm.), Utah (Marjum Fm.), South China (Shuijingtuo Fm. and Shipai Fm.) and Siberia (Sinsk Fm.) (Conway Morris and Robison, 1988; Ponomarenko, 2005; Zhang and Hua, 2005; Chang et al., 2018a). However, Cambrorhytium is much larger (30-50 mm long) than Protoconites. Cambrorhytium major is also characterized by faint tentacle-like structures and transverse annulations. In their original diagnosis, Chen et al. (1994) noted annulations on Protoconites minor, but careful re-examination by Xiao et al. (2002) revealed no such features. Archotuba conoidalis (Hou et al., 1999) from the lower Cambrian Chengjiang Biota also shares a broadly similar overall shape with Protoconites, but like Cambrorhytium is much larger and bears transverse annulations not seen in Protoconites. Lantianella and Piyuania, similar tubular genera from the Ediacaran Lantian Biota in South China (Yuan et al., 2011, 2016; Wan et al., 2016), also have tentacle-like structures, transverse annulations and internal structures which distinguish them from $P$. minor. Protoconites also bears similarities to Sphenothallus from Cambrian Stages 3-Wuliuan in South China (Shuijingtuo Fm., Niutitang Fm., Shipai Fm., and Kaili Fm.) (Zhu et al., 2000; Peng et al., 2005; Muscente and Xiao, 2015; Chang et al., 2018a). However, Protoconites can be easily distinguished from Sphenothallus by lacking a pair of robust, longitudinal thickenings and transverse ribs. While $P$. minor lacks tentacle-like structures, transverse annulations and internal structures seen in Cambrorhytium, Archotuba conoidalis, Lantianella, and Piyuania, broad morphological similarities may implicate a close phylogenetic relationship between these taxa.

Occurrence. The holotype and Ediacaran specimens are derived from the upper Doushantuo Fm. black shales at Miaohe, Yinchang city, Hubei Province (Chen et al., 1994; Ding et al., 1996; Chen et al., 2002; Xiao et al., 2002; Yuan et al., 2002) and Taoying, Jiangkou county, Guizhou Province (Zhao et al., 2004; Wang et al., 2005, 2011). The material described herein is derived from the middle Yanjiahe Fm. silty shale (Bed 3, Terreneuvian, Fortunian), Yichang area, Hubei Province.

\section{ACKNOWLEDGMENTS}

This research is funded by the National Natural Science Foundation of China (Grant Nos. 41890844, 41890840, 41472015, 41672009, 41621003, 41772010, 41720104002, 41930319, 41702010), Strategic Priority Research Program of Chinese Academy of Sciences (Grant No. XDB26000000), Key Scientific and Technological Innovation Team Project in Shaanxi Province, State Key Laboratory of Palaeobiology and Stratigraphy (Nanjing Institute of Geology and Palaeontology, CAS) (No. 203106), and the Ministry of Science and the Overseas Expertise Introduction Centre for Discipline Innovation Project (111) of the Ministry of Education of China (No. D17013). Yanlong Chen was supported by the China Postdoctoral Science Foundation (No. 2017T100766).

\section{REFERENCES}

Adams, D.C., Rohlf, F.J., and Slice, D.E. 2004. Geometric morphometrics: ten years of progress following the 'revolution'. Italian Journal of Zoology, 71:5-16. https://doi.org/10.1080/ 11250000409356545

Adams, D.C., Rohlf, F.J., and Slice, D.E. 2013. A field comes of age: geometric morphometrics in the 21 st century. Hystrix, the Italian Journal of Mammalogy, 24:7-14. https://doi.org/10.4404/ hystrix-24.1-6283

Ahn, S.Y. and Zhu, M.Y. 2017. Lowermost Cambrian acritarchs from the Yanjiahe Formation, South China: implication for defining the base of the Cambrian in the Yangtze Platform. Geological Magazine, 154:1217-1231. https://doi.org/10.1017/S0016756816001369 
Aris-Brosou, S. and Yang, Z. 2003. Bayesian models of episodic evolution support a late Precambrian explosive diversification of the Metazoa. Molecular Biology and Evolution, 20:1947-1954. https://doi.org/10.1093/molbev/msg226

Bell, M. 2014. Patterns In palaeontology: Trends of body-size evolution in the fossil record-a growing field. Palaeontology Online, 4:1-9. http://www.palaeontologyonline.com/articles/ 2014/trends-body-size-evolution-fossil-record-growing-field

Blair, J.E. 2009. Animals (Metazoa), p. 223-230. In Hedges, S.B. and Kumar, S. (eds.), The Timetree of Life. Oxford University Press, Oxford.

Bookstein, F.L. 1997a. Landmark methods for forms without landmarks: morphometrics of group differences in outline shape. Medical Image Analysis, 1:225-243. https://doi.org/10.1016/ S1361-8415(97)85012-8

Bookstein, F.L. 1997b. Shape and the information in medical images: a decade of the morphometric synthesis. Computer Vision and Image Understanding, 66:97-118. https:// doi.org/10.1006/cviu.1997.0607

Bromham, L., Rambaut, A., Fortey, R., Cooper, A., and Penny, D. 1998. Testing the Cambrian explosion hypothesis by using a molecular dating technique. Proceedings of the National Academy of Sciences of the United States of America, 95:12386-12389. https://doi.org/ 10.1073/pnas.95.21.12386

Cai, Y.P., Xiao, S.H., Li, G.X., and Hua, H. 2019. Diverse biomineralizing animals in the terminal Ediacaran Period herald the Cambrian explosion. Geology, 47:1-5. https://doi.org/10.1130/ G45949.1

Chang, S., Feng, Q.L., Clausen, S., and Zhang, L. 2017. Sponge spicules from the Lower Cambrian in the Yanjiahe Formation, South China: The earliest biomineralizing sponge record. Palaeogeography, Palaeoclimatology, Palaeoecology, 474:36-44. https://doi.org/ 10.1016/j.palaeo.2016.06.032

Chang, S., Clausen, S., Zhang, L., Feng, Q.L., Steiner, M., Bottjer, D.J., Zhang, Y., and Shi, M. 2018a. New probable cnidarian fossils from the Lower Cambrian of the three gorges area, South China, and their ecological implications. Palaeogeography, Palaeoclimatology, Palaeoecology, 505:150-166. https://doi.org/10.1016/j.palaeo.2018.05.039

Chang, S., Feng, Q.L., and Zhang, L. 2018b. New siliceous microfossils from the Terreneuvian Yanjiahe Formation, South China: the possible earliest radiolarian fossil record. Journal of Earth Science, 29:912-919. https://doi.org/10.1007/s12583-017-0960-0

Chen, J.Y. 2004. The Dawn of Animal World. Jiangsu Science and Technology Press, Nanjing, China. (In Chinese)

Chen, J.Y. and Zhou, G.Q. 1997. Biology of the Chengjiang fauna. Bulletin of the National Museum of Natural Science (Taichung), 10:11-105.

Chen, J.Y., Zhou, G.Q., Zhu, M.Y., and Yeh, K.Y. 1996. The Chengjiang Biota: A Unique Window of the Cambrian Explosion. National Museum of Natural History, Taichung. (In Chinese)

Chen, M.E., Xiao, Z.Z., and Yuan, X.L. 1994. A new assemblage of megafossils-Miaohe Biota from upper Sinian Doushantuo Formation, Yangtze Gorges. Acta Palaeontologica Sinica, 33:391-403. (In Chinese with English abstract)

Chen, P. 1984. Discovery of Lower Cambrian small shelly fossils from Jijiapo, Yichang, west Hubei and its significance. Professional Papers of Stratigraphy and Palaeontology, 13:49-64. (In Chinese with English abstract)

Chen, X.H., Wang, X.F., Wang, C.S., Chen, L.D., and Chen, H.M. 2002. The Sinian System, p. 23-52. In Wang, X.F., Chen, X.H., Zhang, R.J., Ma, D.Q., Chen, F.W., Wei, C.S., Wang, C.S., Chen, L.D., Chen, H.M., Li, Z.H., Feng, S.N., Duan, Q.F., Xu, G.H., Niu, Z.J., Meng, F.S., Zhang, Z.L., Yao, H.Z., and Huang, Z.X. (eds.), Protection of Precise Geological Remains in the Yangtze Gorges Area, China with the Study of the Archean-Mesozoic Multiple Stratigraphic Subdivision and Sea-level Change. Geological Publishing House, Beijing, China. (In Chinese)

Chen, Y.L., Neubauer, T.A., Krystyn, L., and Richoz, S. 2016. Allometry in Anisian (Middle Triassic) segminiplanate conodonts and its implications for conodont taxonomy. Palaeontology, 59:725-741. https://doi.org/10.1111/pala.12253

Clauset, A. and Erwin, D.H. 2008. The evolution and distribution of species body size. Science, 321:399-401. https://doi.org/10.1126/science.1157534

Conway Morris, S. and Robison, R.A. 1988. More soft-bodied animals and algae from the Middle Cambrian of Utah and British Columbia. The University of Kansas Paleontological Contributions, 122:18-24. https://kuscholarworks.ku.edu/handle/1808/3691 
Conway Morris, S., Peel, J.S., Higgins, A.K., Soper, N.J., and Davis, N.C. 1987. A Burgess shale-like fauna from the Lower Cambrian of North Greenland. Nature, 326:181-183. https:// doi.org/10.1038/326181a0

Cooney, C.R., Bright, J.A., Capp, E.J., Chira, A.M., Hughes, E.C., Moody, C.J., Nouri L.O., Varley, Z.K., and Thomas, G.H. 2017. Mega-evolutionary dynamics of the adaptive radiation of birds. Nature, 542:344-347. https://doi.org/10.1038/nature21074

Cruz, R.A.L., Pante, M.J.R., and Rohlf, F.J. 2012. Geometric morphometric analysis of shell shape variation in Conus (Gastropoda: Conidae). Zoological Journal of the Linnean Society, 165:296-310. https://doi.org/10.1111/j.1096-3642.2011.00806.x

Ding, L.F., Li, Y., and Chen, H.X. 1992. Discovery of Micrhystridium regulare from SinianCambrian boundary strata in Yichang, Hubei, and its stratigraphic significance. Acta Micropalaeontologica Sinica, 9:303-309. (In Chinese with English abstract)

Ding, L.F., Li, Y., Hu, X.S., Xiao, Y.P., Su, C.Q., and Huang, J.C. 1996. Sinian Miaohe Biota of China. Geology Publishing House, Beijing, China. (In Chinese with English summary)

Dong, L., Xiao, S.H., Shen, B., Zhou, C.M., Li, G.X., and Yao, J.X. 2009. Basal Cambrian microfossils from the Yangtze Gorges area (South China) and the Aksu area (Tarim Block, northwestern China). Journal of Paleontology, 83:30-44. https://doi.org/10.1017/ S0022336000058108

Gillooly, J.F., Brown, J.H., West, G.B., Savage, V.M., and Charnov, E.L. 2001. Effects of size and temperature on metabolic rate. Science, 293:2248-2251. https://doi.org/10.1126/ science.1061967

Gunz, P. and Mitteroecker, P. 2013. Semilandmarks: a method for quantifying curves and surfaces. Hystrix, the Italian Journal of Mammalogy, 24:103-109. https://doi.org/10.4404/ hystrix-24.1-6292

Gunz, P., Mitteroecker, P., and Bookstein, F.L. 2005. Semilandmarks in three dimensions, p. 7398. In Slice, D.E. (ed.), Modern Morphometrics in Physical Anthropology. Kluwer Academic/ Plenum Publishers, New York. https://doi.org/10.1007/0-387-27614-9

Guo, J.F., Li, Y., Han, J., Zhang, X.L., Zhang, Z.F., Ou, Q., Liu, J.N., Shu, D.G., Maruyama, S., and Komiya, T. 2008. Fossil association from the Lower Cambrian Yanjiahe Formation in the Yangtze Gorges Area, Hubei, South China. Acta Geologica Sinica (English Edition), 82:11241132. https://doi.org/10.1111/j.1755-6724.2008.tb00712.x

Guo, J.F., Li, Y., Han, J., Zhang, X.L., Zhang, Z.F., Ou, Q., and Shu, D.G. 2009. Discovery of genus Protoconites Chen et al., 1994 from Yanjiahe Formation, Terreneuvian of the Three Gorge area, South China. Progress in Natural Science, 19:180-184. (In Chinese)

Guo, J.F., Li, Y., and Shu, D.G. 2010a. Fossil macroscopic algae from the Yanjiahe Formation, Terreneuvian of the Three Gorge area, South China. Acta Palaeontologica Sinica, 49:336342. (In Chinese with English abstract)

Guo, J.F., Li, Y., and Shu, D.G. 2010b. Cyanobacteria fossils from the Yanjiahe Formation, Terreneuvian Cambrian, Yichang, Hubei. Acta Micropalaeontologica Sinica, 27:144-149. (In Chinese with English abstract)

Guo, J.F., Li, Y., Han, H.P., Ou, Q., Zhou, J.R., and Zheng, Y.J. 2012. New macroscopic problematic fossil from the Early Cambrian Yanjiahe Biota, Yichang, Hubei, China. Acta Geologica Sinica (English Edition), 86:791-798. https://doi.org/10.1111/j.17556724.2012.00706.x

Guo, J.F., Li, Y., and Li, G.X. 2014. Small shelly fossils from the Early Cambrian Yanjiahe Formation, Yichang, Hubei, China. Gondwana Research, 25:999-1007. https://doi.org/ 10.1016/j.gr.2013.03.007

Guo, J.F., Qiang, Y.Q., Song, Z.C., Zheng, Y.J., Yao, X.Y., Xiao, L., and Li, X.C. 2017. Research progress and prospect on the Early Cambrian Yanjiahe Biota. Acta Palaeontologica Sinica, 56:461-475. (In Chinese with English abstract)

Guo, J.F, Han, J., Van Iten, H., Song, Z.C., Qiang, Y.Q., Wang, W.Z., Zhang, Z.F, Li, G.X., Sun, Y.F., and Sun, J. 2020a. A new tetraradial olivooid (Medusozoa) from the Lower Cambrian (Stage 2) Yanjiahe Formation, South China. Journal of Paleontology, 94:457-466. https:// doi.org/10.1017/jpa.2019.101

Guo, J.F, Han, J., Van Iten, H., Wang, X., Qiang, Y.Q., Song, Z.C., Wang, W.Z., Zhang, Z.F., and Li, G.X. 2020b. A fourteen-faced hexangulaconulariid from the early Cambrian (Stage 2) Yanjiahe Formation, South China. Journal of Paleontology, 94:45-55. https://doi.org/10.1017/ jpa.2019.56 
Guo, J.F., Li, G.X., Qiang, Y.Q., Song, Z.C., Zhang, Z.F., Han, J., and Wang, W.Z. 2020c. Watsonella crosbyi from the lower Cambrian (Terreneuvian, Stage 2) Yanjiahe Formation in Three Gorges area, South China. Palaeoworld, in press. https://doi.org/10.1016/ j.palwor.2020.04.006

Hammer, Ø., Harper, D.A.T., and Ryan, P.D. 2001. PAST: Paleontological Statistics Software package for education and data analysis. Palaeontologia Electronica, 4.1.4:1-9. https:// palaeo-electronica.org/2001_1/past/issue1_01.htm

Hone, D.V.E. and Benton, M.J. 2005. The evolution of large size: how does Cope's Rule work? Trends in Ecology and Evolution, 20:4-6. https://doi.org/10.1016/j.tree.2004.10.012

Hou, X.G., Bergström, J., Wang, H.F., Feng, X.H., and Chen, A.L. 1999. The Chengjiang Fauna: Exceptionally Well-preserved Animals from 530 Million Years Ago. Yunnan Science and Technology Press, Kunming, China. (In Chinese with English summary)

Hou, X.G., Aldridge, R.J., Bergström, J., Siveter, D.J., Siveter, D.J., and Feng, X.H. 2004. The Cambrian Fossils of Chengjiang, China: The Flowering of Early Animal Life. Blackwell Publishing, Oxford. https://doi.org/10.1002/9781118896372

Karahan, A., Borsa, P., Gucu, A.C., Kandemir, I., Ozkan, E., Orek, Y.A., Acan, S.C., Koban, E., and Togan, I. 2014. Geometric morphometrics, Fourier analysis of otolith shape, and nuclearDNA markers distinguish two anchovy species (Engraulis, spp.) in the Eastern Mediterranean Sea. Fisheries Research, 159:45-55. https://doi.org/10.1016/ j.fishres.2014.05.009

Klingenberg, C.P. 1998. Heterochrony and allometry: the analysis of evolutionary change in ontogeny. Biological Reviews of the Cambridge Philosophical Society, 73:79-123. https:// doi.org/10.1111/j.1469-185X.1997.tb00026.x

Knouft, J.H. and Page, L.M. 2003. The evolution of body size in extant groups of North American freshwater fishes: speciation, size distributions, and Cope's Rule. The American Naturalist, 161:413-421. https://doi.org/10.1086/346133

Li, G.X., Steiner, M., Zhu, X.J., Yang, A.H., Wang, H.F., and Erdtmann, B.D. 2007. Early Cambrian metazoan fossil record of South China: Generic diversity and radiation patterns. Palaeogeography, Palaeoclimatology, Palaeoecology, 254:229-249. https://doi.org/10.1016/ j.palaeo.2007.03.017

Matthews, T. and Stynder, D.D. 2011. An analysis of two species (Soricidae) from the Early Pliocene site of Langebaanweg (West coast, South Africa) using geometric morphometrics, linear measurements, and non-metric characters. Géobios, 44:87-99. https://doi.org/10.1016/ j.geobios.2010.07.003

McCall, G.J.H. 2006. The Vendian (Ediacaran) in the geological record: enigmas in geology's prelude to the Cambrian explosion. Earth-Science Reviews, 77:1-229. https://doi.org/ 10.1016/j.earscirev.2005.08.004

Meert, J.G. and Lieberman, B.S. 2004. A palaeomagnetic and palaeobiogeographical perspective on latest Neoproterozoic and Early Cambrian tectonic events. Journal of the Geological Society (London), 161:477-487. https://doi.org/10.1144/0016-764903-107

Meert, J.G. and Lieberman, B.S. 2008. The Neoproterozoic assembly of Gondwana and its relationship to the Ediacaran-Cambrian radiation. Gondwana Research, 14:5-21. https:// doi.org/10.1016/j.gr.2007.06.007

Mitteroecker, P. and Gunz, P. 2009. Advances in geometric morphometrics. Evolutionary Biology, 36:235-247. https://doi.org/10.1007/s11692-009-9055-x

Mosimann, J.E. 1970. Size allometry: size and shape variables with characterizations of the lognormal and generalized gamma distributions. Journal of the American Statistical Association, 65:930-945. https://doi.org/10.1080/01621459.1970.10481136

Moysiuk, J., Smith, M.R., and Caron, J.B. 2017. Hyoliths are Palaeozoic lophophorates. Nature, 541, 394-397. https://doi.org/10.1038/nature20804

Muscente, A.D. and Xiao, S.H. 2015. New occurrences of in the lower Cambrian of South China: implications for its affinities and taphonomic demineralization of shelly fossils. Palaeogeography, Palaeoclimatology, Palaeoecology, 437:141-164. https://doi.org/10.1016/ j.palaeo.2015.07.041

O'Gorman, E.J. and Hone, D.W.E. 2012. Correction: body size distribution of the dinosaurs. PloS One, 7:e51925. https://doi.org/10.1371/annotation/032ce6c0-22e3-4ae8-997a40859 bcb5609 
Okada, Y., Sawaki, Y., Komiya, T., Hirata, T., Takahata, N., Sano, Y., Han, J., and Maruyama, S. 2014. New chronological constraints for Cryogenian to Cambrian rocks in the Three Gorges, Weng'an and Chengjiang areas, South China. Gondwana Research, 25:1027-1044. https:// doi.org/10.1016/j.gr.2013.05.001

Peng, J., Babcock, L.E., Zhao, Y.L., Wang, P.L., and Yang, R.J. 2005. Cambrian from Guizhou Province, China: early sessile predators. Palaeogeography, Palaeoclimatology, Palaeoecology, 220:119-127. https://doi.org/10.1016/j.palaeo.2004.09.014

Peterson, K.J., Lyons, J.B., Nowak, K.S., Takacs, C.M., Wargo, M.J., and Mcpeek, M.A. 2004. Estimating metazoan divergence times with a molecular clock. Proceedings of the National Academy of Sciences of the United States of America, 101:6536-6541. https://doi.org/ 10.1073/pnas.0401670101

Peterson, K.J., Cotton, J.A., Gehling, J.G., and Pisani, D. 2008. The Ediacaran emergence of bilaterians: congruence between the genetic and the geological fossil records. Philosophical Transactions of the Royal Society of London B: Biological Sciences, 363:1435-1443. https:// doi.org/10.1098/rstb.2007.2233

Ponomarenko, A.G. 2005. Unique Sinsk localities of Early Cambrian organisms (Siberian platform). Russian Academy of Sciences, Transactions of the Palaeontological Institute, Nauka, Moscow, 284:1-143. (In Russian)

Rohlf, F.J. 2010a. TpsDig, digitize landmarks and outlines, version 2.16. Department of Ecology \& Evolution, State University of New York at Stony Brook.

Rohlf, F.J. 2010b. TpsRelw, relative warps analysis, version 1.49. Department of Ecology \& Evolution, State University of New York at Stony Brook. http://life.bio.sunysb.edu/morph

Rohlf, F.J. 2011a. TpsUtil, file utility program, version 1.47. Department of Ecology \& Evolution, State University of New York at Stony Brook. http://life.bio.sunysb.edu/morph

Rohlf, F.J. 2011b. TpsRegr, shape regression, version 1.38. Department of Ecology \& Evolution, State University of New York at Stony Brook. http://life.bio.sunysb.edu/morph

Shang, X.D., Liu, P.J., Yang, B., Chen, S.M., and Wang, C.C. 2016. Ecology and phylogenetic affinity of the Early Cambrian tubular microfossil . Palaeontology, 59:13-28. https://doi.org/ 10.1111/pala.12201

Shi, Y.K. and MacLeod, N. 2016. Identification of life-history stages in fusulinid foraminifera. Marine Micropaleontology, 122:87-98. https://doi.org/10.1016/j.marmicro.2015.12.002

Shu, D.G. 2008. Cambrian explosion: birth of tree of animals. Gondwana Research, 14:219-240. https://doi.org/10.1016/j.gr.2007.08.004

Shu, D.G., Isozaki, Y., Zhang, X.L., Han, J., and Maruyama, S. 2014. Birth and early evolution of metazoans. Gondwana Research, 25:884-895. https://doi.org/10.1016/j.gr.2013.09.001

Steiner M., Li, G.X., Qian, Y., Zhu, M.Y., and Erdtmann, B.D. 2007. Neoproterozoic to Early Cambrian small shelly fossil assemblages and a revised biostratigraphic correlation of the Yangtze Platform (China). Palaeogeography, Palaeoclimatology, Palaeoecology, 254:67-99. https://doi.org/10.1016/j.palaeo.2007.03.046

Sun, H.J., Smith, M.R., Zeng, H., Zhao, F.C., Li, G.X., and Zhu, M.Y. 2018. Hyoliths with pedicles illuminate the origin of the brachiopod body plan. Proceedings of the Royal Society B: Biological Sciences, 285:20181780. https://doi.org/10.1098/rspb.2018.1780

Topper, T.P., Guo, J.F., Clausen, S., Skovsted, C.B., and Zhang Z.F. 2019. A stem group echinoderm from the basal Cambrian of China and the origins of Ambulacraria. Nature Communications, 10:1366. https://doi.org/10.1038/s41467-019-09059-3

Verrill, A.E. 1865. Classification of polyps (extract condensed from synopsis of the polyps and corals of the North Pacific exploring expedition under Commodore C. Ringgold and Captain John Rogers, U.S.N.). Communications of the Essex Institute, 4:145-152.

Wan, B., Yuan, X.L., Chen, Z., Guan, C.G., Pang, K., Tang, Q., and Xiao, S.H. 2016. Systematic description of putative animal fossils from the early Ediacaran Lantian Formation of South China. Palaeontology, 59:515-532. https://doi.org/10.1111/pala.12242

Wang, Y., He, M.H., Yu, M.Y., Zhao, Y.L., Peng, J., Yang, R.J., and Zhang, Z.H. 2005. Preliminary discussion on ecological characteristics and buried environments of Miaohe-type Biota during the Late Doushantuoian of Sinian in northeastern Guizhou Province. Journal of Palaeogeography, 7:327-335. (In Chinese with English abstract)

Wang, Y., Chen, H.D., Wang, X.L., and Huang, Y.M. 2011. Evolution of the Ediacaran Doushantuoian meta-paleo-community in northeast Guizhou, South China. Acta Geologica Sinica (English Edition), 85:533-543. https://doi.org/10.1111/j.1755-6724.2011.00448.x 
Werner, B. 1966. (Scyphozoa, Coronatae) und seine direkte Abstammung von den fossilen Conulata. Helgolander wissenschaftliche Meeresuntersuchungen, 13:317-347. https:// doi.org/10.1007/BF01611953

Wray, G.A., Levinton, J.S., and Shapiro, L.H. 1996. Molecular evidence for deep Precambrian divergences among metazoan phyla. Science, 274:568-573. https://doi.org/10.1126/ science.274.5287.568

Xiao, S.H., Yuan, X.L., Steiner, M., and Knoll, A.H. 2002. Macroscopic carbonaceous compressions in a terminal Proterozoic shale: a systematic reassessment of the Miaohe Biota, South China. Journal of Paleontology, 76:347-376. https://doi.org/10.1017/ s0022336000041743

Yao, J.X., Xiao, S.H., Yin, L.M., Li, G.X., and Yuan, X.L. 2005. Basal Cambrian microfossils from the Yurtus and Xishanblaq formations (Tarim, north-west China): Systematic revision and biostratigraphic correlation of -like acritarchs from China. Palaeontology, 48:687-708. https:// doi.org/10.1111/j.1475-4983.2005.00484.x

Yuan, X.L., Xiao, S.H., Yin, L.M., Knoll, A.H., Zhou, C.M., and Mu, X.N. 2002. Doushantuo Fossils: Life on the Eve of Animal Radiation. University of Science and Technology of China Press, Hefei, China. (In Chinese)

Yuan, X.L., Chen, Z., Xiao, S.H., Zhou, C.M., and Hua, H., 2011. An early Ediacaran assemblage of macroscopic and morphologically differentiated eukaryotes. Nature, 470:390-393. https:// doi.org/10.1038/nature09810

Yuan, X.L., Wan, B., Guan, C.G., Chen, Z., Zhou, C.M., Xiao, S.H., Wang, W., Pang, K., Tang, Q., and Hua, H. 2016. The Lantian Biota. Shanghai Science and Technology Press, Shanghai, China. (In Chinese)

Zelditch, M.L., Swiderski, D.L., Sheets, H.D., and Fink, W.L. 2004. Geometric Morphometrics for Biologists: A Primer. Elsevier Academic Press, New York and London. https://doi.org/ 10.1016/b978-0-12-778460-1.x5000-5

Zhang, X.L. and Hua, H. 2005. Soft-bodied fossils from the Shipai Formation, Lower Cambrian of the Three Gorge area, South China. Geological Magazine, 142:699-709. https://doi.org/ 10.1017/S0016756805000518

Zhang, X.L., Shu, D.G., Han, J., Zhang, Z.F., Liu, J.N., and Fu, D.J. 2014. Triggers for the Cambrian explosion: hypotheses and problems. Gondwana Research, 25:896-909. https:// doi.org/10.1016/j.gr.2013.06.001

Zhao, Y.L., Chen, M.E., Peng, J., Yu, M.Y., He, M.H., Wang, Y., Yang, R.J., Wang, P.L., and Zhang, Z.H. 2004. Discovery of a Miaohe-type Biota from the Neoproterozoic Doushantuo Formation in Jiangkou County, Guizhou Province, China. Chinese Science Bulletin, 49:22242226.

Zhu, M.Y. and Strauss, H. 2007. From snowball earth to the Cambrian bioradiation: Calibration of Ediacaran-Cambrian earth history in South China. Palaeogeography, Palaeoclimatology, Palaeoecology, 254:1-6.

Zhu, M.Y., Van Iten, H., Cox, R.S., Zhao, Y.L., and Erdtmann, B.D. 2000. Occurrence of Matthew and Hall in the Lower Cambrian of China. Paläontologische Zeitschrift, 74:227-238. https:// doi.org/10.1007/BF02988098

Zhu, M.Y., Zhang, J.M., Steiner, M., Yang, A.H., Li, G.X., and Erdtmann, B.D. 2003. SinianCambrian stratigraphic framework for shallow- to deep-water environments of the Yangtze Platform: an integrated approach. Progress in Natural Science, 13:951-960. https://doi.org/ 10.1080/10020070312331344710

Zhu, M.Y., Zhuravlev, A.Yu., Wood, R.A., Zhao, F.C., and Sukhov, S.S. 2017. A deep root for the Cambrian explosion: Implications of new bio- and chemostratigraphy from the Siberian Platform. Geology, 45:459-462. https://doi.org/10.1130/G38865.1 


\section{APPENDICES}

The following data files associated with this study are available in the Dryad Digital Repository https://doi.org/10.5061/dryad.7wm37pvr8.

Supplementary Table S1. Centroid size and RW scores of overall specimens (1048 specimens, un-mirrored). Supplied in zipped file at https://palaeo-electronica.org/content/2020/3177-fossilplants-from-tennessee.

Supplementary Table S2. Centroid size and RW scores of straight shelled specimens (722 specimens, laterally bended specimens excluded). Supplied in zipped file at https://palaeo-electronica.org/content/2020/3177-fossil-plants-from-tennessee.

Supplementary Table S3. Centroid size and RW scores of overall specimens (1048 specimens, partly mirrored). Supplied in zipped file at https://palaeo-electronica.org/content/2020/3177-fossil-plants-from-tennessee.

Supplementary Table S4. Centroid size and RW scores of bent specimens (326 bent specimens, partly mirrored). Supplied in zipped file at https://palaeo-electronica.org/content/2020/ 3177-fossil-plants-from-tennessee. 